\title{
Psychometric properties and factor structure of Persian version of Delay Discounting Scale
}

\author{
Hashem Jebraeili $^{* *}$ iD, Mahsa Felehgari², Tannaz Seydi² \\ 1. Assistant Professor of Health Psychology, Department of Psychology, School of Social and Educational Sciences, Razi University, \\ Kermanshah, Iran \\ 2. MA Student of General Psychology, School of Social and Educational Sciences, Razi University, Kermanshah, Iran
}

Recieved: 26 Jul. 2018

Revised: 9 Jan. 2020

Accepted: 3 Feb. 2020

\section{Keywords}

Delay discounting

Monetary choice questionnaire

Psychometric properties

Corresponding author

Hashem Jebraeili, Iran, Kerman-

shah, Oil Sq, Shahid Beheshti

Blvd., Daneshmand Alley, School

of Social Sciences and Education,

Department of Psychology

Email: H.jebraeili@yahoo.com

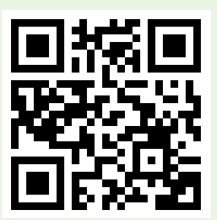

doi.org/10.30699/icss.22.2.12

\section{Abstract}

Introduction: Considering the need to provide valid instruments for research and clinical work, the present study aimed to develop and evaluate the psychometric properties and factor structure of the Persian version of the monetary choice questionnaire.

Methods: In this cross-sectional survey, 400 students were selected through convenience sampling from all students of Kermanshah universities. The data were collected through Consideration of Future Consequences scale and Monetary Choice Questionnaire and were analyzed using statistical methods of Cronbach's alpha, intra-class and Pearson correlation tests, and the exploratory factor analysis.

Results: The findings showed that the internal consistency of the scale using Cronbach's alpha was 0.89 , its split-half reliability was 0.88 , and its test-retest reliability was 0.78 for a three week. The exploratory factor analysis results showed that the single-factor structure and the three-factor structure of the questionnaire were valid.

Conclusion: According to findings, the monetary choice questionnaire has acceptable validity and reliability, and given the relatively short time it takes to be completed. So, it can be an appropriate tool for employing in both clinical and research situations. 


\title{
ويخَىهاى روانسنجى و ساختار عاملى نسخه فارسى مقياس سنجش كاهش اهميت تأخيرى
}

\author{
هاشم جبرائيلى "(D) ، مهسا فعله كرى'، طناز صيدى'
}

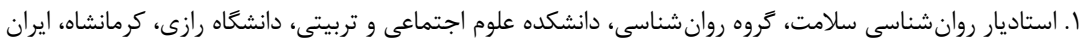

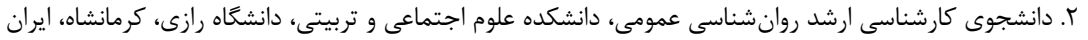

مقدمه: با توجه به ضرورت فراهم ساختن ابزارهاى معتبر جهت يُوهش و كار بالينى، يُوهش حاضر با هدف ساخت و بررسى ويزگگىهاى روانسنجى و ساختار عاملى نسخه فارسى يرسشنامه انتخاب يولى انجام شد.

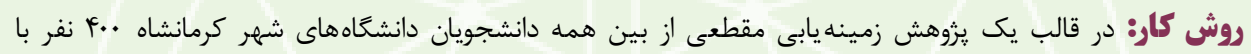
استفاده از روش نمونه كيرى در دسترس انتخاب شدند. دادهاى يُوهش از طريق مقياس در نظر گرفتن ييامدهاى آينده و يرسشنامه انتخاب يولى كردآورى شد. تجزيه و تحليل دادها با استفاده از روشهاى آمارى آلفاى كرونباخ، آزمونهاى همبستكى درون كلاسى، همبستخى بيرسون و تحليل عاملى اكتشافى به وسيله نرمافزار SPSS-22 انجام كرفت. يافتهاها: نتايج نشان داد كه همسانى درونى مقياس با استفاده از آلفاى كرونباخ 199/•، پايايى تصنيف آن 11/• و پايايى بازآزمايى آن براى يك دوره زمانى سه هفتگى / / • مى باشد. همجنين نتايج تحليل عاملى اكتشافى نشان داد كه

$$
\text { هم ساختار تك عاملى و هم ساختار سه عاملى ترسشنامه معتبر است. }
$$

نتيجه گَيرى: مىتوان كَفت كه نسخه فارسى يرسشنامه انتخاب يولى از روايى و پايايى قابل قبولى برخوردار است. همجنين با توجه به زمان نسبتاً كوتاهى كه براى ير كردن آن مورد نياز است مىتواند ابزار مناسبى براى به كاركيرى هم در موقعيتهاى بالينى و هم در موقعيتهاى يروهشى باشد.

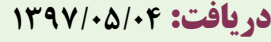

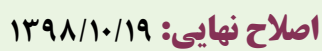

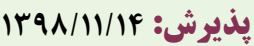
وارْهاى كليلدى

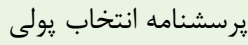
كاهش اهميت تأخيرى

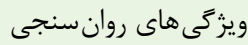

\section{نويسنده مسنول}

هاشم جبرائيلى، ايران، كرمانشاه، ميدان نفت، بلوار شهيد بهشتى، كوجه دانشمند،

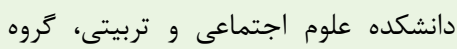
روانشناسى

ايميل:H.jebraeili@yahoo.com

\section{口74 Tysc Fenetrits

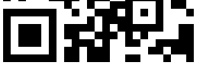

dol doi.org/10.30699/icss.22.2.12

مقدمبه

اندام بهترى داشته باشيهم. اما مشكل اينجاست كه آن تكه كيك، اگرجه در مجموع براى ما ارزش كمترى هم دارد، همين اكنون در دسترس و مستلزم تلاش كمى در حدود بلند كردن جنعال است، در حالى كه تناسب اندام ممكن است مستلزم زمان و كوشش باشد. در اين مثال اگر جه عوامل مختلفى وجود دارد كه بايد در نظر گرفته شود، اما مىتوان
بيشتر ما هنگام انتخاب ياداشهاى فورى را به پاداشهاى تاخيرى و

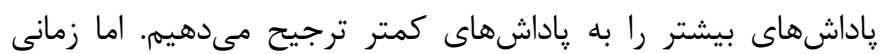
كه اين جنبdها، يعنى ياداش كمم در حال حاضر يا پاداش زياد بعداً، در مقابل هم قرار مى گيرند انتخاب ييجيده مىشود. براى مثال، بسيارى از ما ترجيح مىدهيم كه به جاى خوردن تكهاى از يك كيك تناسب 
تأخيرى فرضى ياداشها در انسانها ارتباط نيرومندى با كاهش اهميت

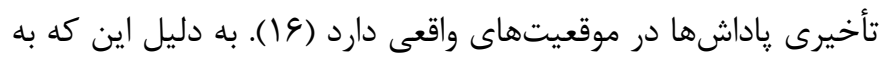

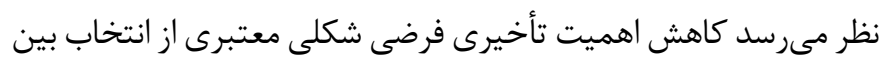

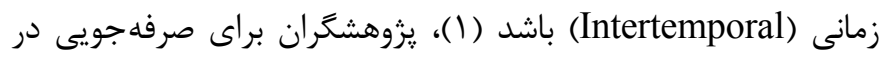

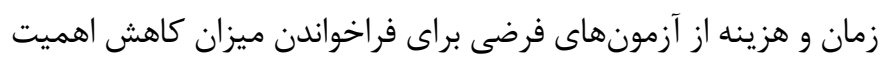

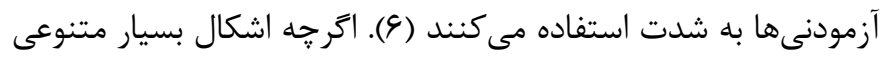

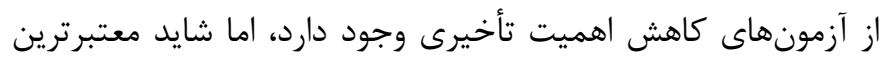

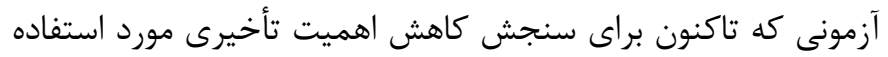
قرار كرفته است، يرسشنامه انتخاب يولى است كه، نسبت به ابزاهاى ديخر كه به صورت تكاليف رايانهاى هستند، از اين امتياز برخوردار است

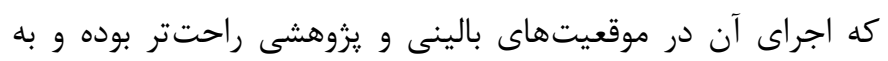

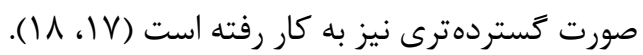

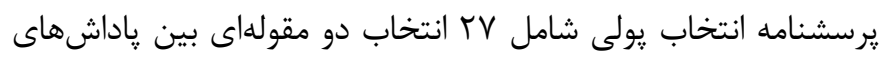

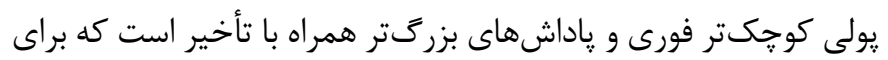

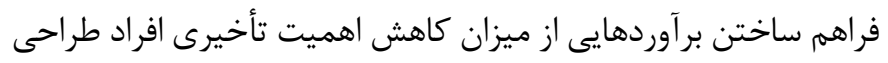

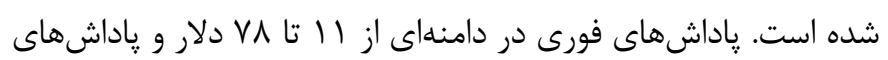

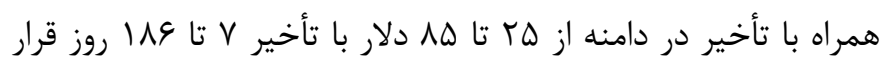

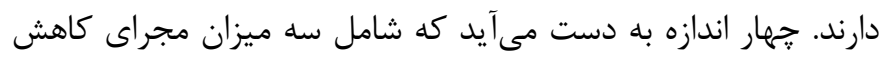

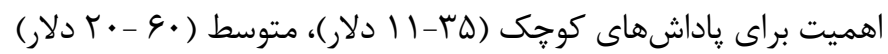

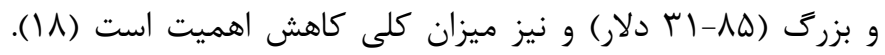

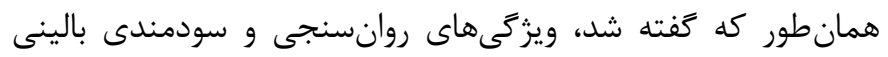

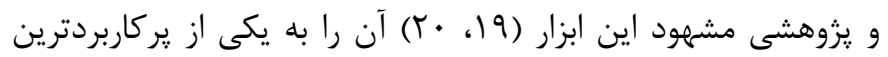

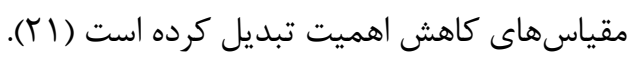
Kirby

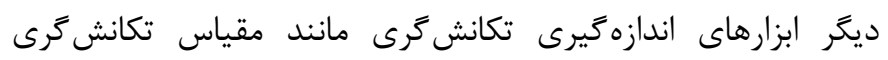
Barratt Impulsiveness Scale) Barratt ميانگَين نمرات يرسشنامه انتخاب يولى در مصرف كنندًان مواد نسبت

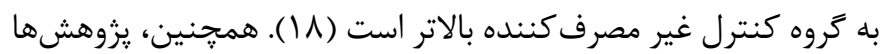
نشان داده است كه نمرات يرسشنامه انتخاب يولى همبستگى بالايى با

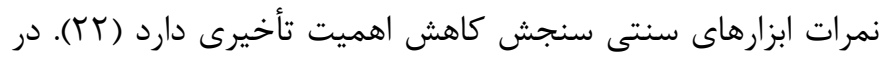

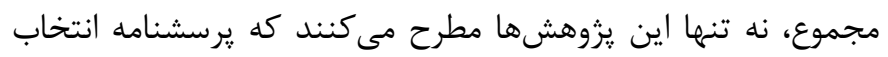

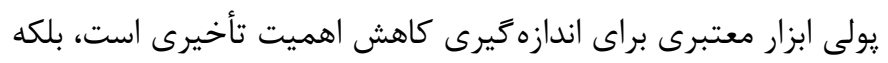

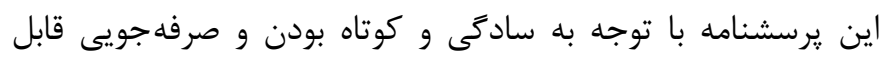

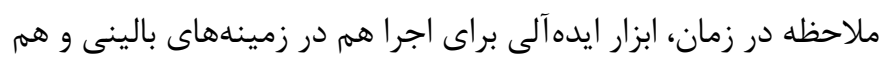

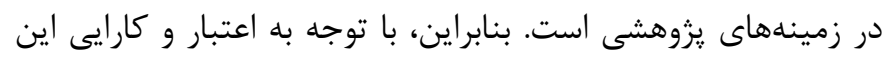
يرسشنامه و نبود ابزارى براى سنجش كاهش اهميت تاخيرى به زبان

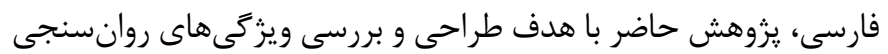

مشكل اساسى را كه در كار است مشاهده كرد: ياداشهاى فورى به طور نامتناسبى وزن بيشترى در تصميمات ما دارند. براى مثال، دانشجويان

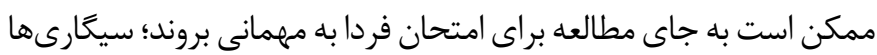

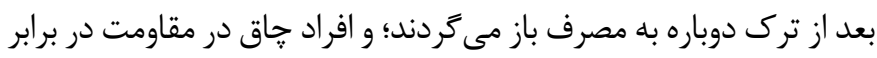
خوردن شكست مى خورند (1).

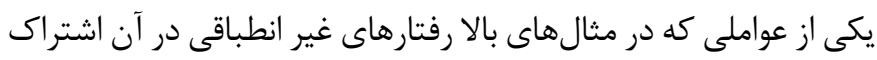

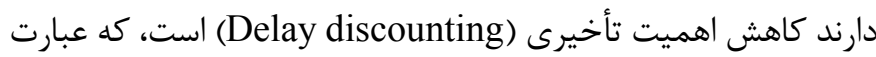

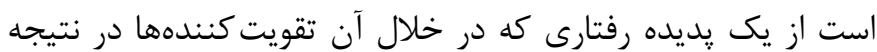

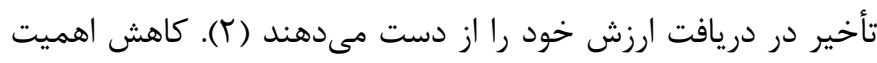

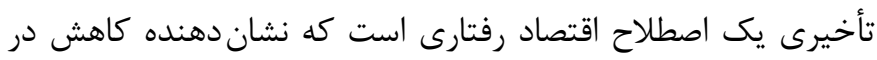

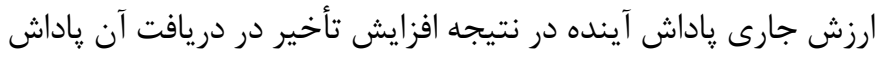

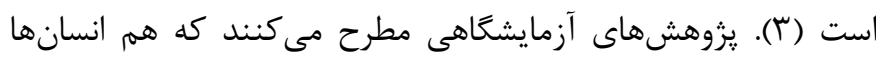

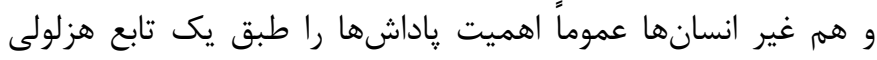

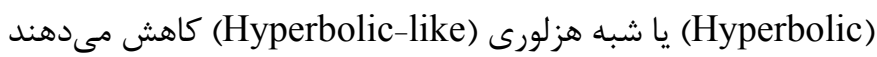

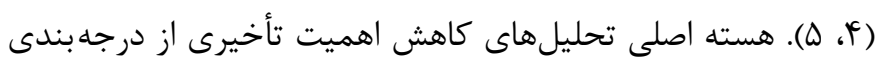

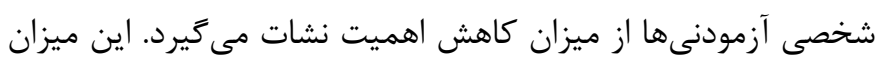

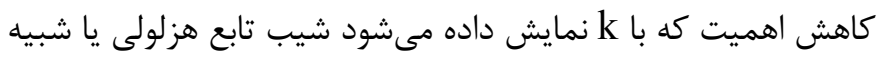

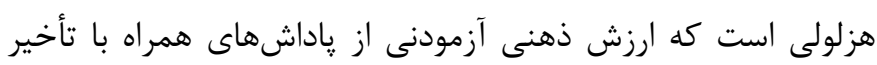

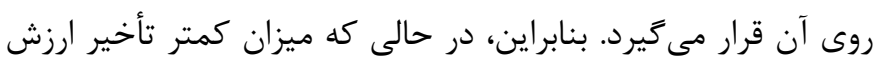

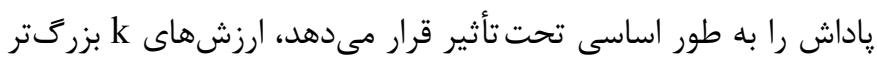

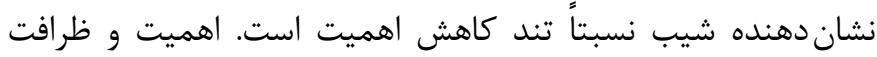

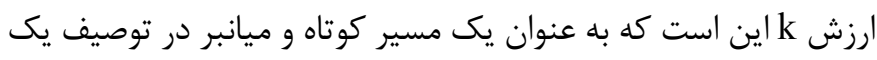

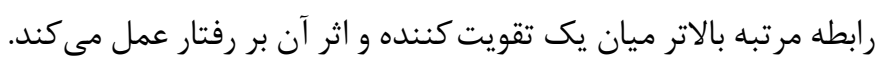

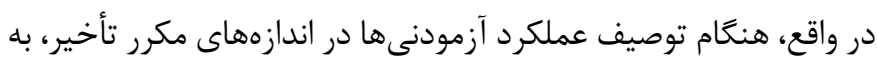

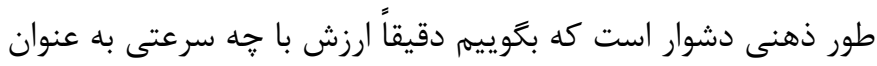

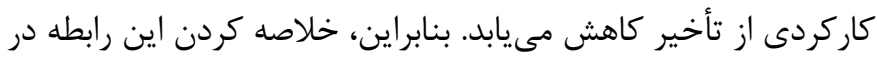

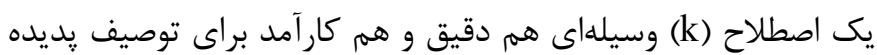

كاهش اهميت است (؟). (ك)

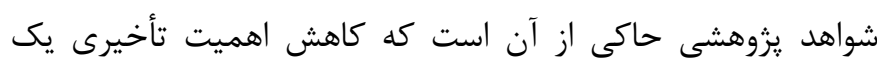

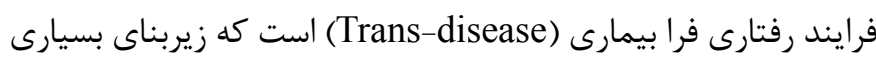

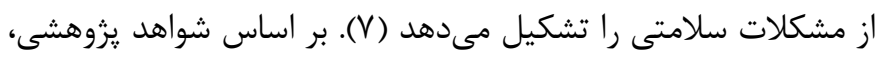

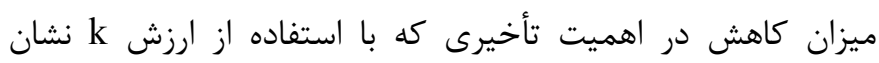

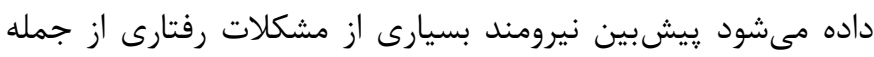

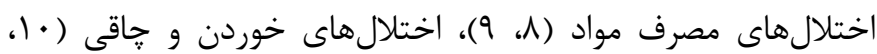

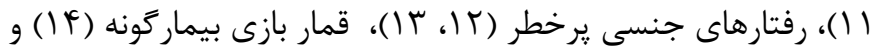
وابستخى به فن آورى (ها (1) است. هم شواهد تجربى و هم شواهد بالينى نشان داده است كه كاهش اهميت 


\section{Consideration of) يرسشنامه در نظر كرفتن بيامدهاى آينده}

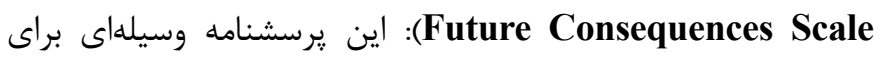

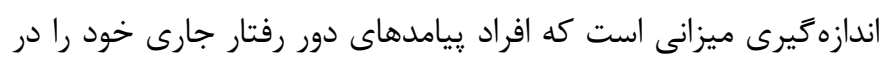

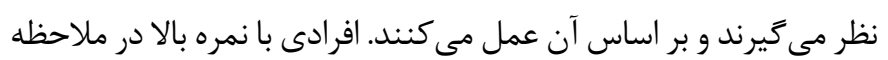

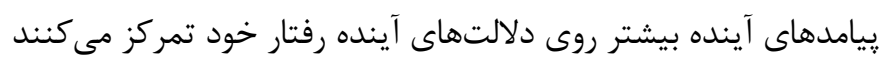

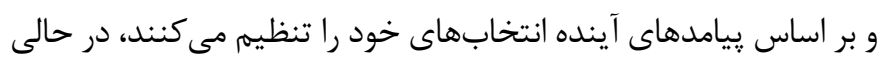

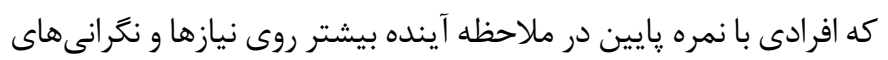

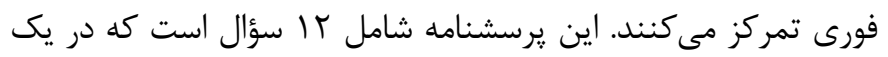

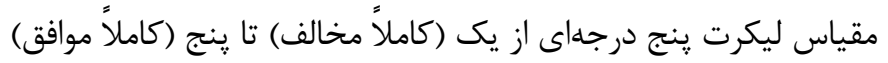

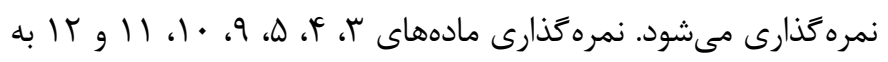

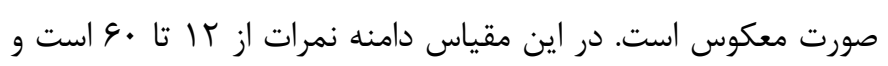

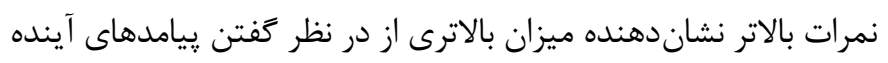

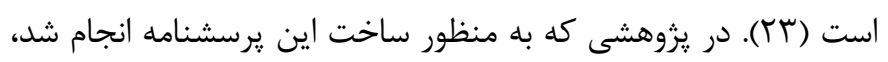

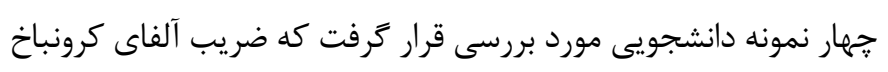

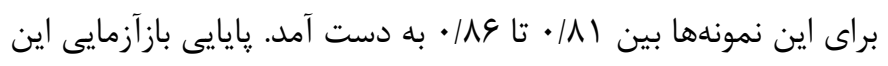

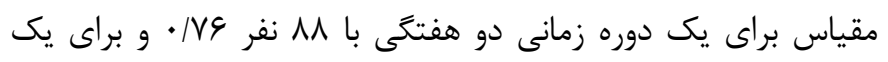

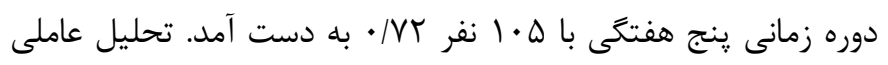

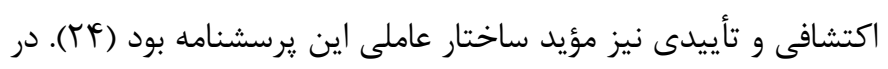

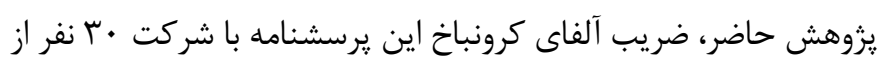

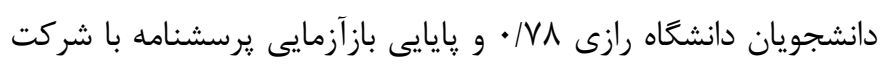

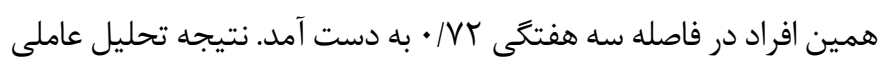

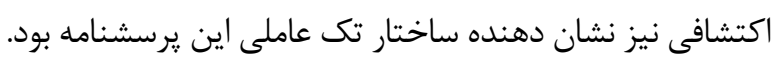
يرسشنامه انتخاب يولى (Monetary Choice Questionnaire):

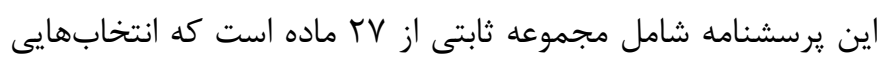

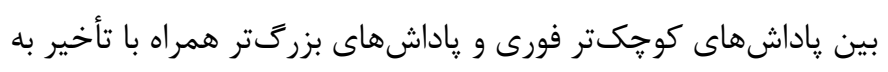

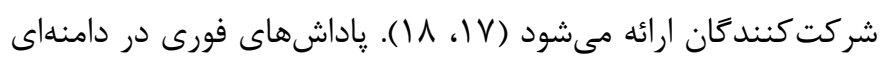

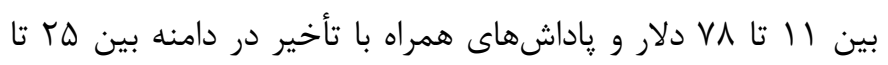

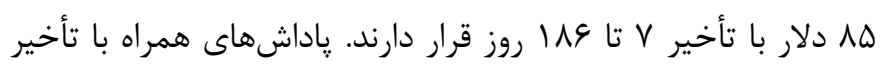

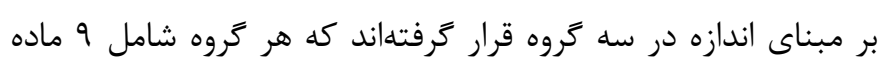

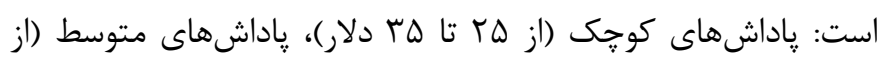

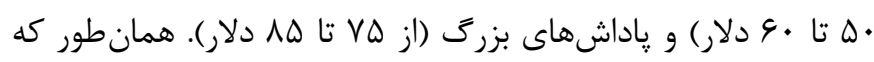

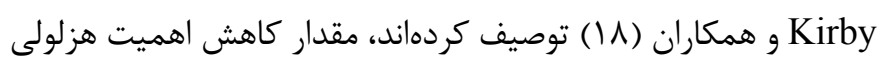

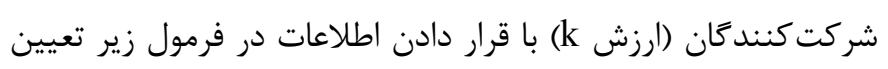

$V_{\text {immediae }}=V_{\text {delayed }} /(1+k D)$
نسخه فارسى يرسشنامه انتخاب يولى انجام كرفت.

دوش كار

يزوهش حاضر از نوع تحليلى_مقطعى بود. جامعه آمارى بروهش حاضر

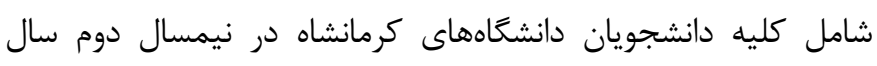

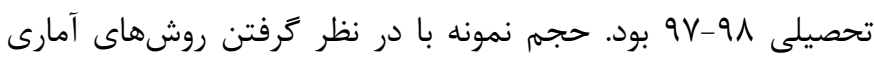

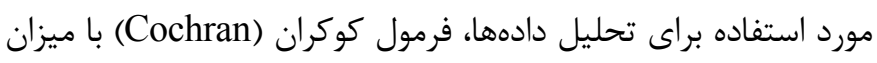

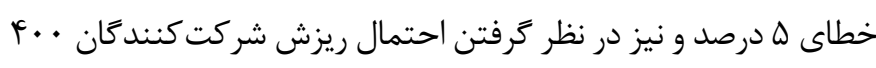

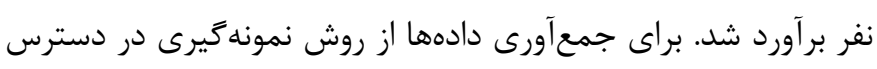

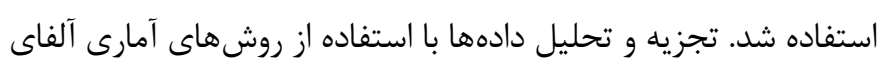

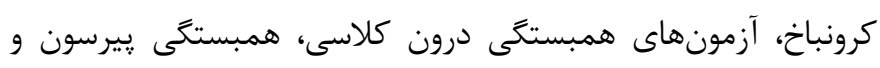

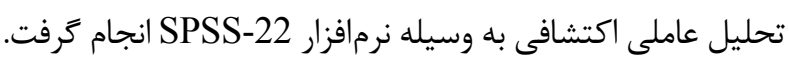

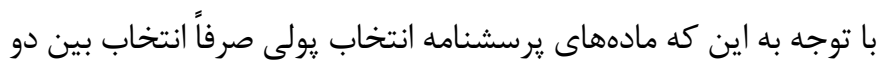

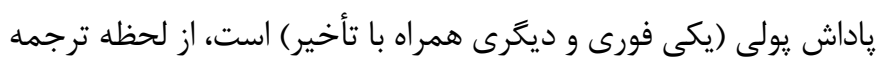

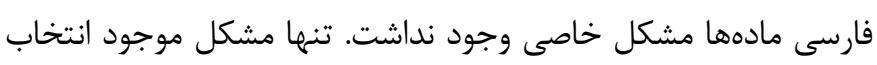

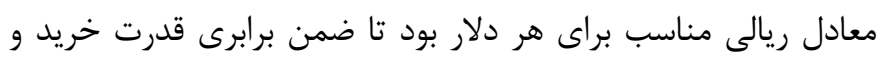

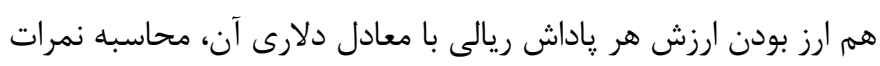

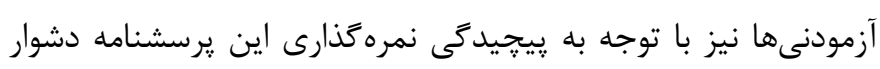

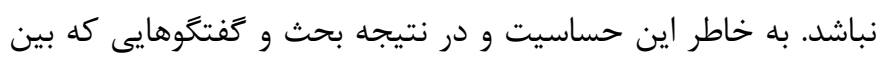

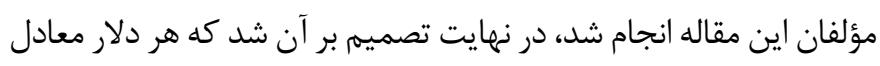

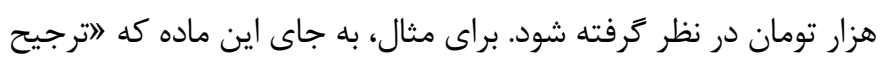

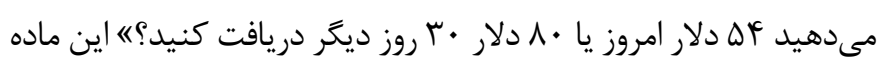

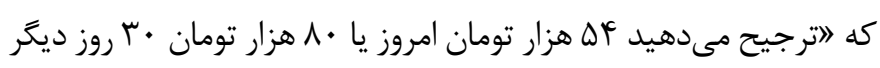

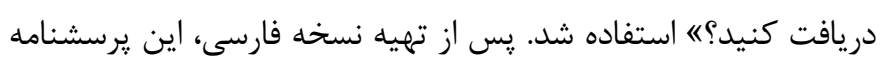

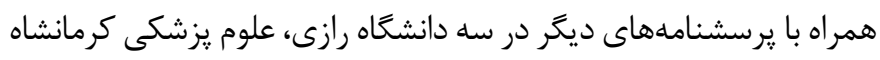

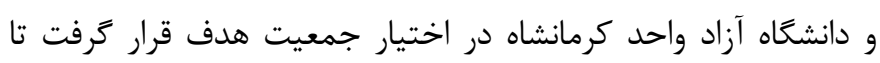

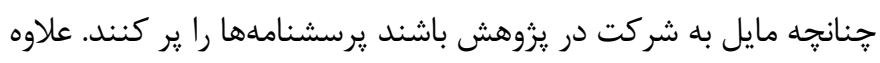

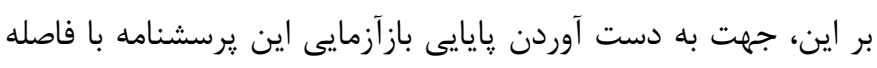

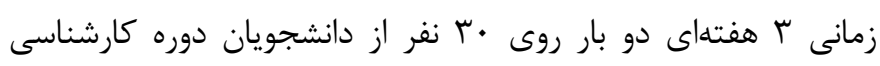

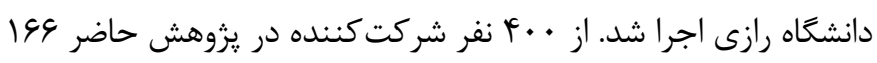

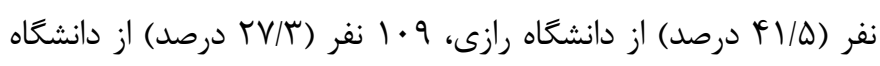

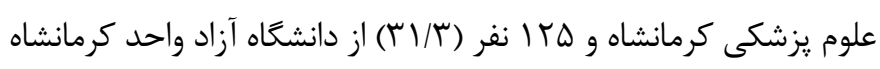

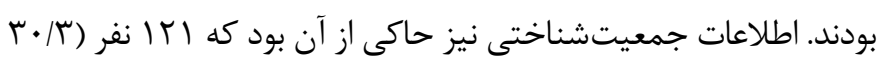
درصد) از شركت كنند

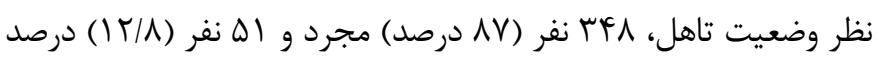

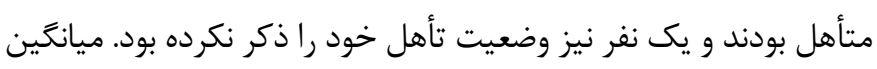

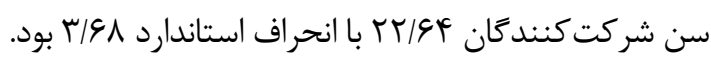


SPSS (ץ) SPS اشاره كرد. در يزوهش حاضر با توجه به سهولت وارد كردن دادها در SPSS از روش دوم استفاده شد.

بافته ها جهت بررسى پايايى نسخه فارسى يرسشنامه انتخاب يولى، نخست اين

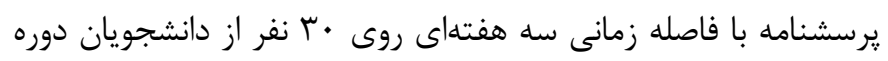

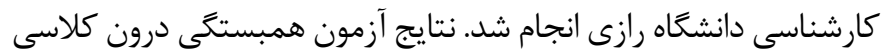
(Intraclass correlation) يايايى بازآزمايى نمره پِاداشهاى كوجى (ارزش k ياداشهاى كوجى)

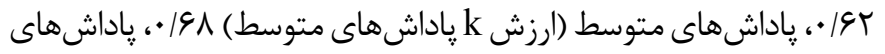

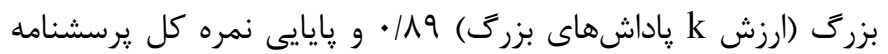

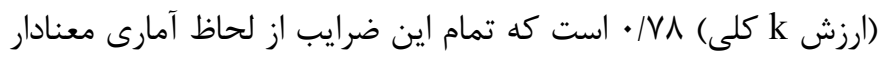

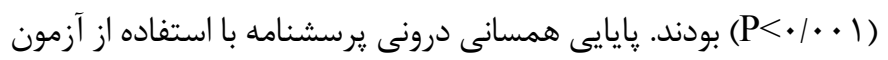

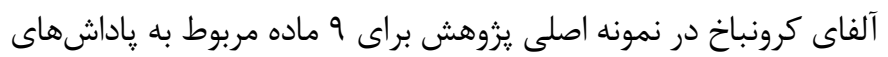

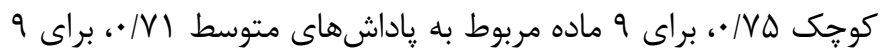
ماده مربوط به پاداشهاى بزرك /V| • و براى تمام مادهاى برسشنامه

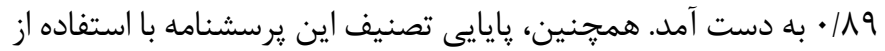
ضريب تصنيف M (Guttman split-half coefficient) Guttman

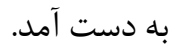

كه در آن V ارزش ياداش به دلار و D تأخير به روز است. در يرسشنامه

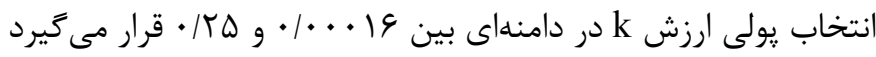

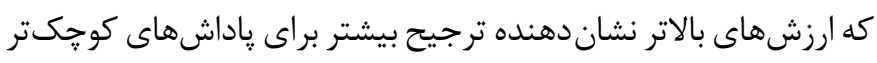

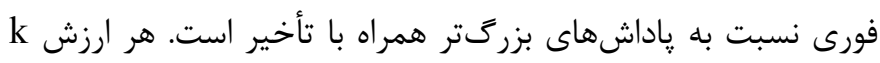

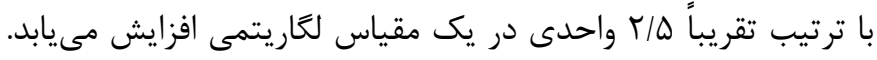
ارزشهاى k با در نظر كرفتن نقطه ميانى بين اندازههاى كاهش اهميت مرتبط با هر ماده و سيس بررسى الكوى ياسخدهى شركت كنندكان در كوششهاى مختلف برآورد مىشود تا تعيين شود كه كدام ارزش k با بال

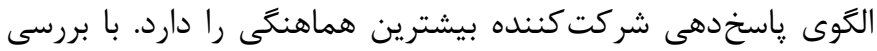

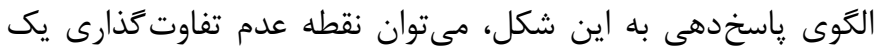

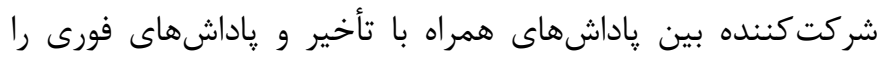
استنباط كرد. براى تعيين مناسبترين ارزش k، نسبت انتخابهاى

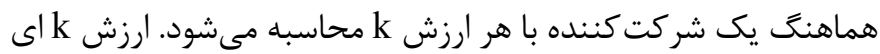

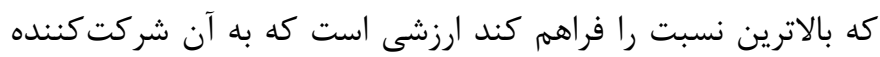
اختصاص داده مىشود. اكر دو يا جند ارزش نسبت مشابهى را داشته

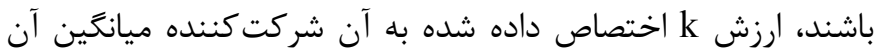

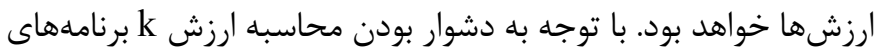
رايانهاى مختلفى براى انجام اين كار نوشته شده است كه از جمله آنها مىتوان به محاسبه ارزش k از طريق اكسل (9) و سينتكس (Syntax)

جدول ا. ضرايب آلفاى كرونباخ سه بخش و كل يرسشنامه انتخاب يولى

\begin{tabular}{|c|c|}
\hline ضريب آلفاى كرونباخ & مادهها \\
\hline$\cdot / V \Delta$ & 9 ماده مربوط به پاداش هاى كوجى \\
\hline$\cdot|V|$ & 9 ماده مربوط به ياداش هاى متوسط \\
\hline$\cdot / V I$ & 9 ماده مربوط به ياداش هاى بزرى \\
\hline$\cdot 119$ & كل مادهها \\
\hline
\end{tabular}

نشاندهنده مناسب بودن دادهها براى تحليل عاملى اكتشافى بود. نتايج حاصل از اين تحليل، هم بر اساس نمودار سنگريزه (Scree plot) (نمودار () و هم بر اساس درصد واريانس تبيين شده، حاكى از آن بود كه راه حل سه عاملى با تبيين حدود كاه درصد از كل واريانس يرسشنامه، در مقايسه با راهحل تكى عاملى كه تنها حدود • ب درصد از كل واريانس :رسشنامه را تبيين مى كرد، توضيح بهترى براى ساختار عاملى يرسشنامه فراهم مى كند (جدول ؟).
جهت بررسى ساختار عاملى :يرسشنامه از تحليل عاملى اكتشافى با روش تحليل مؤلفههاى اصلى استفاده شد. قبل از استفاده از اين تحليل مناسب بودن دادهها براى انجام تحليل عاملى اكتشافى با استفاده از آزمون كفايت نمونه و آزمون كرويت Olkin measure of sampling adequacy بارتلت Bartlett's test of Sphericity) مورد بررسى قرار گرفت. نتايج حاصل از اين آزمونها ( I / / 


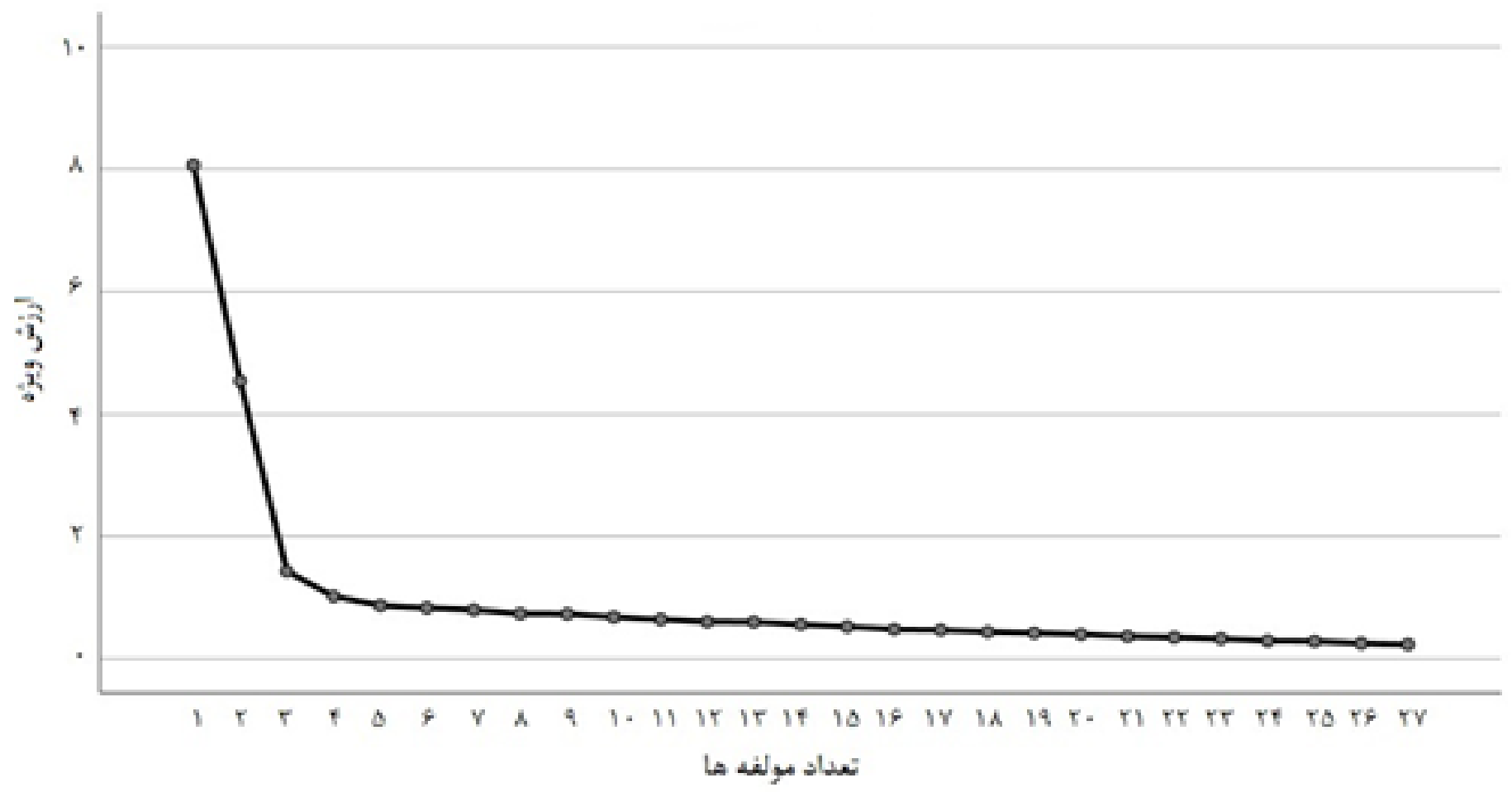

نمودار ا. نمودار سنگَريزه براى تعيين تعداد مناسب عاملها

جدول r. بارهاى عاملى ماده هاى مختلف يرسشنامه انتخاب يولى روى عامل هاى استخراج شده

\begin{tabular}{|c|c|c|c|}
\hline 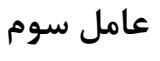 & 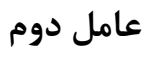 & 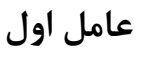 & 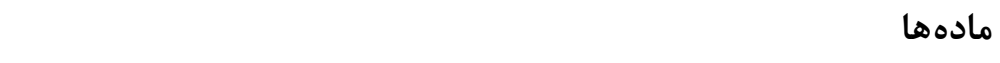 \\
\hline$-\cdot / \cdot r$ & $\cdot / 14$ & $\cdot / \Delta \Lambda$ & ا. ترجيح هF هزار تومان امروز در برابر ترجيح هلهزار تومان IIV روز ديكر \\
\hline זr/. & $\cdot / 1 F$ & $\cdot / f F$ & r. ترجيح هل هزار تومان امروز در برابر ترجيح هل هزار تومان او روز ديگر \\
\hline$\cdot / 10$ &.$/ 1 F$ & $\cdot 109$ & r. ترجيح 19 هزار تومان امروز در برابر ترجيح هr هزار تومان rه روز ديكر \\
\hline$-\cdot \cdot \cdot r$ & $\cdot / V V$ &.$/ \cdot 1$ & F. ترجيح اس هزار تومان امروز در برابر ترجيح ه^ هزار تومان V روز ديگر \\
\hline$\cdot \mid \Delta F$ & $\cdot / K F$ & . /KG & ه. ترجيح Flf هزار تومان امروز در برابر ترجيح ه广 هزار تومان 19 روز ديكر \\
\hline$\cdot / \cdot \Delta$ & $-\cdot / \cdot f$ & $\cdot / V V$ & \&. ترجيح FV هزار تومان امروز در برابر ترجيح •ه هزار تومان ••l روز ديكر \\
\hline r & .199 &.$/ 11$ & V. ترجيح ها هزار تومان امروز در برابر ترجيح هس هزار تومان با روز ديكر \\
\hline .119 & $\cdot / V R$ & $\cdot 1 \cdot r$ & ^. ترجيح ه广 هزار تومان امروز در برابر ترجيح •ع هزار تومان fا روز ديحر \\
\hline$\cdot / \cdot V$ & $-\cdot / \cdot r$ & .199 & 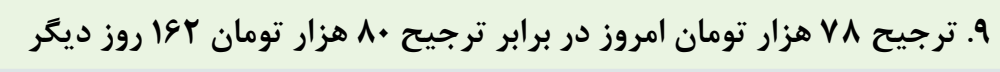 \\
\hline$\cdot / k$. & $-\cdot \cdot \cdot 1$ & $\cdot 109$ & 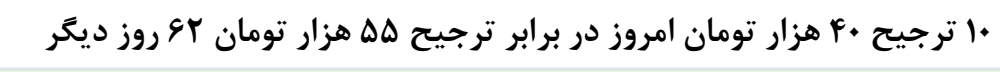 \\
\hline$\cdot / 1$ & $\cdot / v 9$ & $-\cdot \cdot \cdot 1$ & 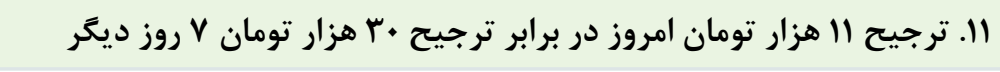 \\
\hline .119 & $\cdot 1 \cdot 1$ & $\cdot 190$ & זا. ترجيح V\& هزار تومان امروز در برابر ترجيح DD هزار تومان 119 روز ديگر \\
\hline$\cdot / 1$ & $\cdot 1 \cdot 1$ & $\cdot \operatorname{lvT}$ & 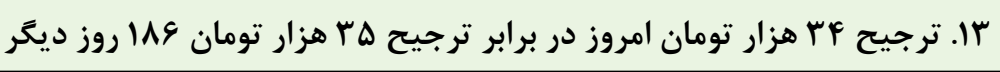 \\
\hline
\end{tabular}




\begin{tabular}{|c|c|c|c|}
\hline 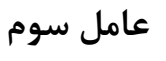 & 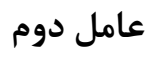 & 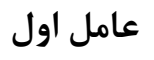 & مادهها \\
\hline$\cdot 19$. & . KT &.$/ 1 T$ & Fا. ترجيح VY هزار تومان امروز در برابر ترجيح •ه هزار تومان اب روز ديكر \\
\hline$\cdot \mid \Delta F$ & $-\cdot / \cdot r$ & $\cdot / 49$ & ها. ترجيح و\& هزار تومان امروز در برابر ترجيح ه^ هزار تومان اه روز ديكر \\
\hline$\cdot \ln$ & $\cdot / \cdot r$ & $\cdot / \Delta \omega$ & 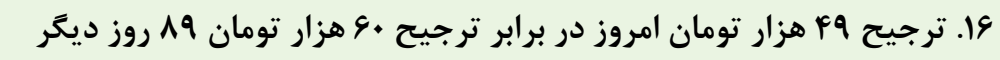 \\
\hline rאן & -.1 .4 & $\cdot 199$ & 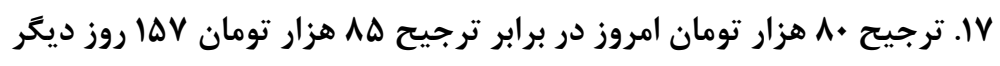 \\
\hline$\cdot \mid \Delta r$ & .1 .9 & . & \ו. ترجيح FF هزار تومان امروز در برابر ترجيح هץ هزار تومان هץ روز ديكر \\
\hline .1 .9 & $\cdot / V \Lambda$ & $-\cdot \cdot \cdot \Delta$ & 19. ترجيح سب هزار تومان امروز در برابر ترجيح •^ هزار تومان fl روز ديكر \\
\hline .1 .9 & $-\cdot / \cdot r$ & $\cdot / V F$ & 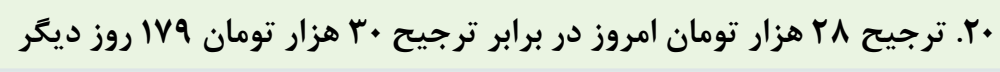 \\
\hline$\cdot|\Lambda|$ & $\cdot / 1$ & .119 & اr. ترجيح FF هزار تومان امروز در برابر ترجيح •ه هزار تومان ·r روز ديگر \\
\hline$\cdot / 1 \mathrm{~F}$ & $-\cdot 1 \cdot 4$ & $\cdot / V \Delta$ & 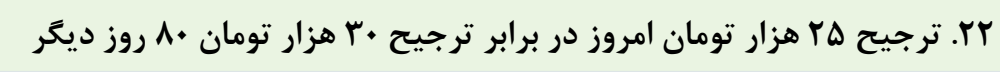 \\
\hline 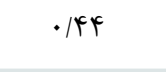 & .194 & $-\cdot / \cdot 1$ & r. ترجيح l هزار تومان امروز در برابر ترجيح VD هزار تومان ·r روز ديكر \\
\hline$\cdot / M F$ & $-\cdot \cdot \cdot \wedge$ & $\cdot / N r$ & FF. ترجيح هزار تومان امروز در برابر ترجيح •4 هزار تومان IIIا روز ديكر \\
\hline $.19 \mathrm{~V}$ & $\cdot / \Gamma \cdot$ & .111 & ها. ترجيح هF هزار تومان امروز در برابر ترجيح •^ هزار تومان •r روز ديكر \\
\hline.$/ I V$ & $-\cdot / \cdot r$ & . IVT & צr. ترجيح r هزار تومان امروز در برابر ترجيح هr هزار تومان צrا روز ديگر \\
\hline $.1 \cdot q$ & $\cdot / V \wedge$ & $-\cdot 111$ & Vr. ترجيح ·r هزار تومان امروز در برابر ترجيح هله هزار تومان V روز ديگر \\
\hline
\end{tabular}

خوبى برخوردار است. در حالى كه ضريب تصنيف Guttman حاكى از آن

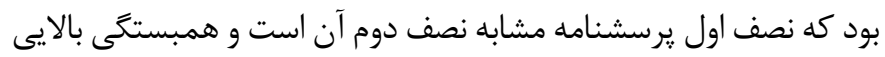
بين نمرات شركت كنندكان در دو قسمت يرسشنامه وجود دارد، ضريب

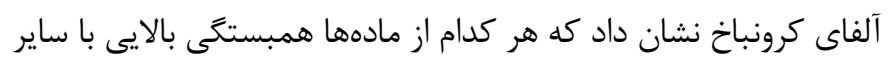

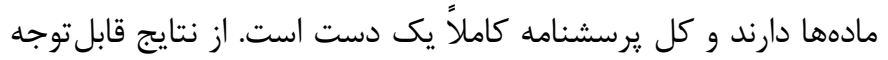

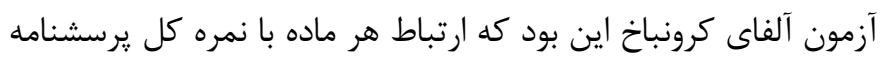

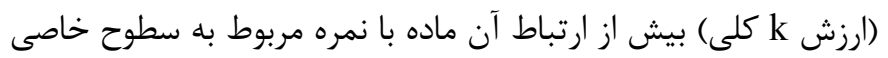

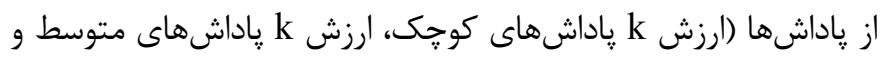

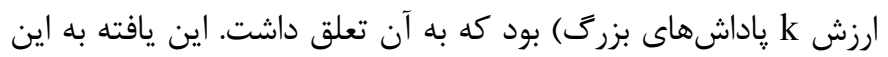

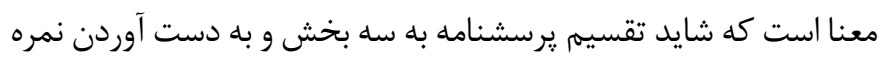
مجزا براى هر بخش خيلى ضرورت نداشته باشد و نمره كل يرسشنامه باله

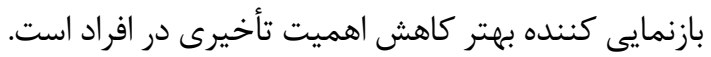

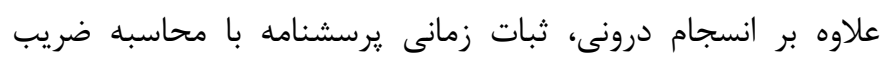

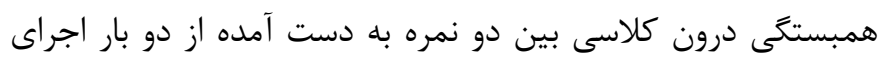

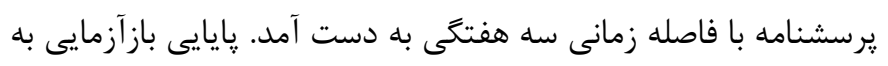

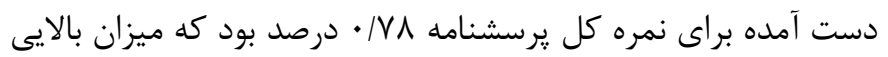
محسوب مىشود و نشاندهنده ثبات زمانى مناسب اين برسشنامه
جهت بررسى روايى ملاكى، همبستگى بين نمرات يرسشنامه كاهش

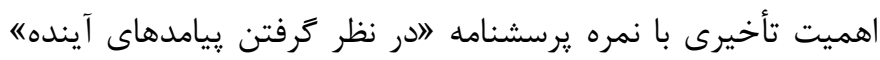

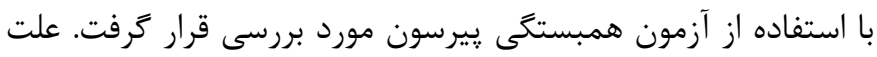

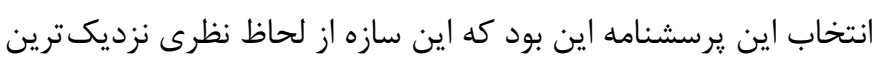

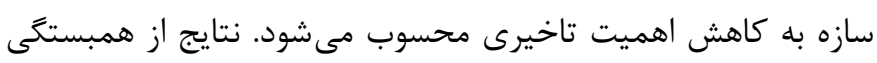

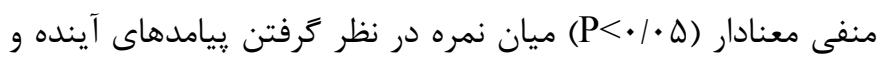

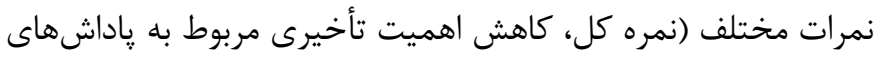

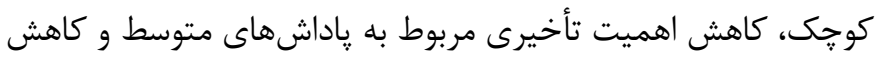

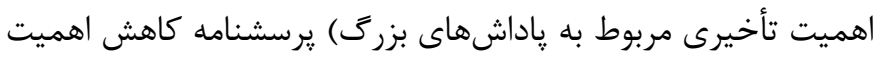

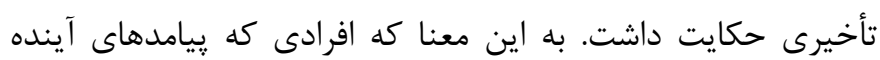

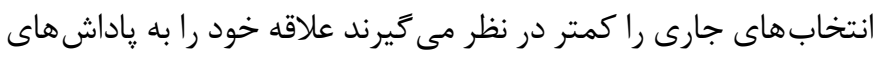
همراه با تاخير سريعتر از دست مى دهند.

يزوهش حاضر با هدف بررسى ويزگى هاى روانسنجى نسخه فارسى

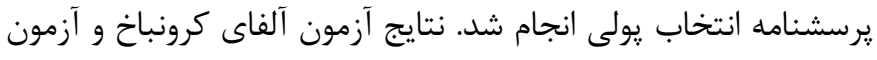
تصنيف Guttman حكايت از آن داشت كه يرسشنامه از انسجام درونى 
اهميت تأخيرى افراد آكاهى كسب كرد. اين يافته همسو با نتايج آزمون

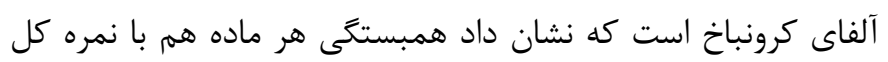

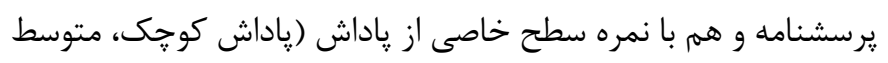
و بزرى) كه بدان تعلق داشت بالاست.

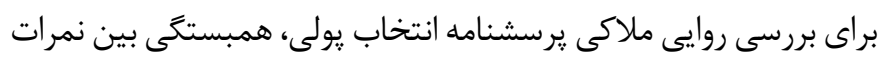

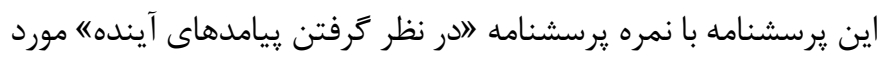

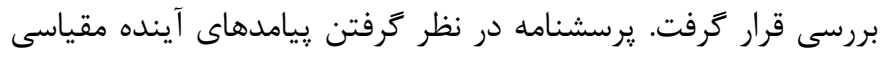

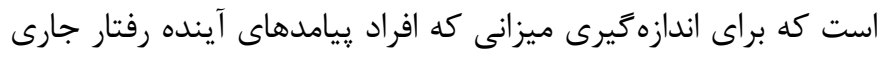

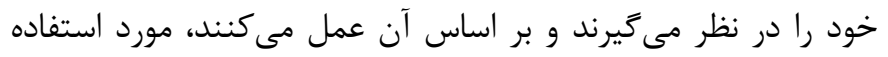

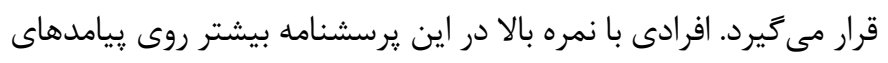

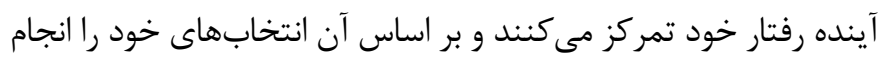

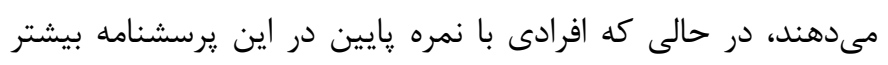

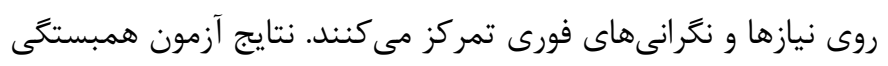

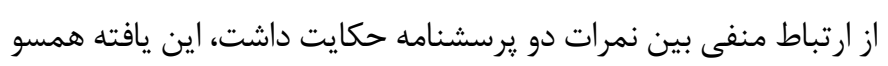

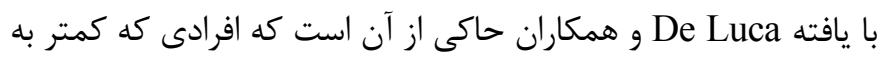

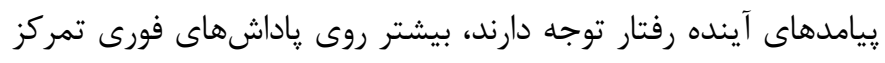
دارند و تصميمات خود را بر اساس ييامدهاى فورى رفتار اتخاذ مى كنيند

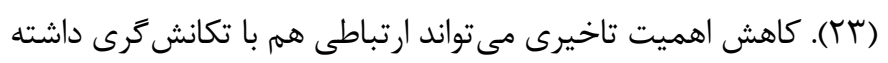

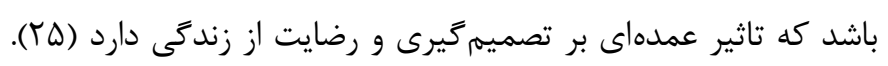

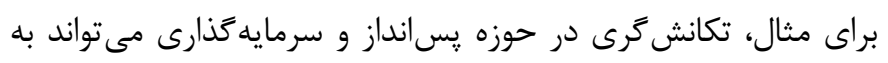

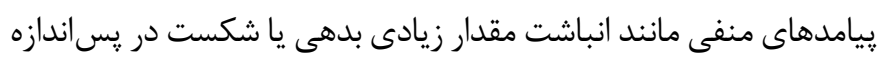

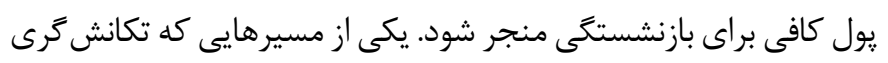

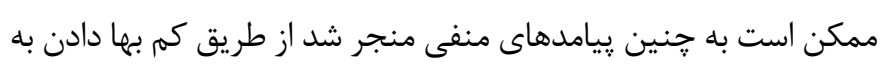

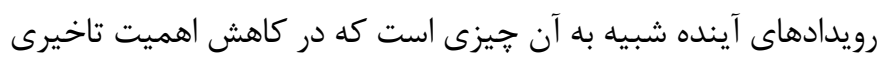

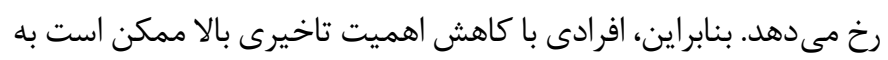

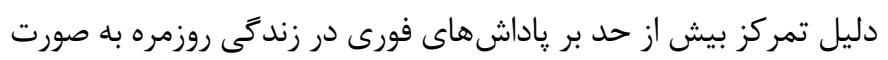

$$
\text { تانش كانر انه تصميم بخيرند. }
$$

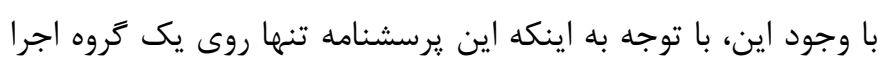

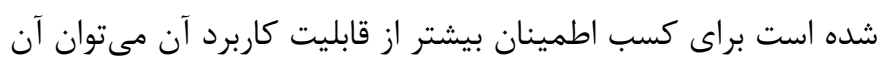

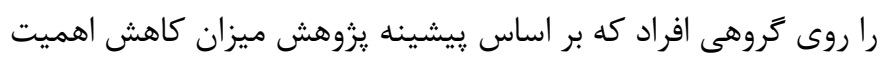

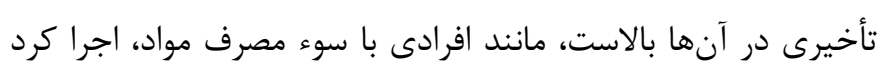

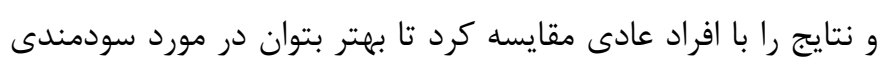

$$
\text { بالينى آن نظر داد. }
$$

\section{نتيجه گيرى} يافتهاى يزوهش حاضر نشان داد كه نسخه فارسى يرسشنامه انتخاب

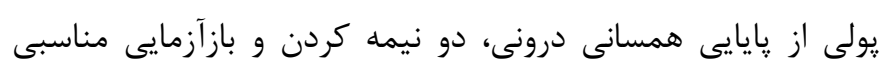

حداقل براى يك دوره زمانى متوسط است. با اين وجود، يافته مههمتر

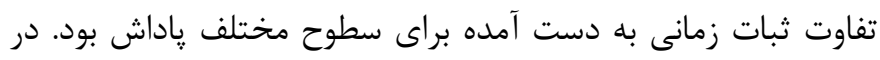

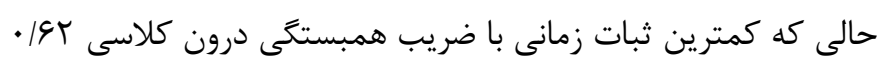

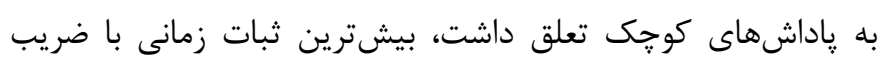

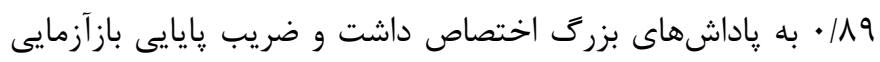

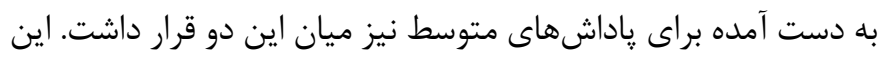

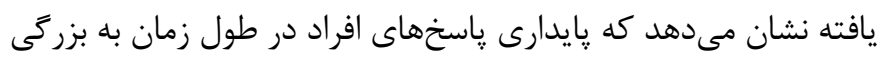

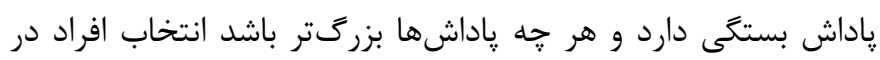

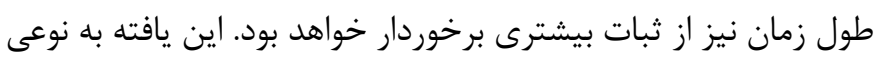

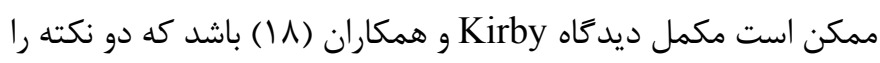

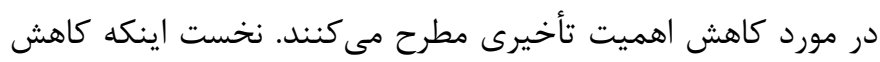

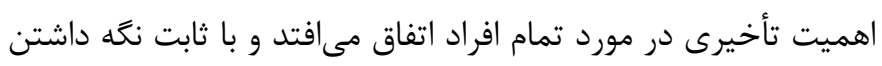

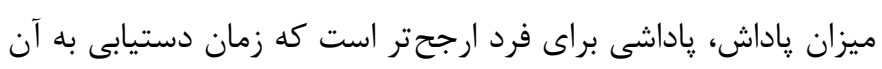

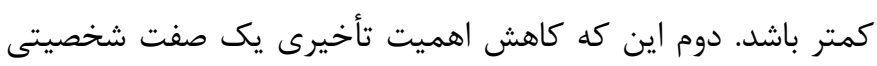

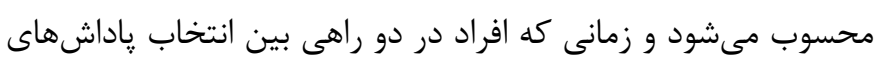

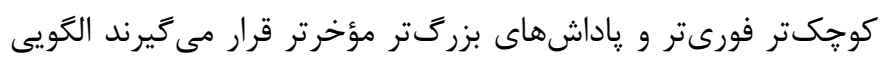

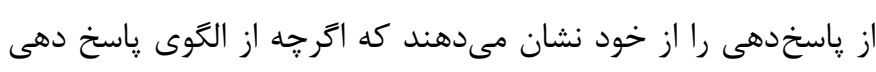

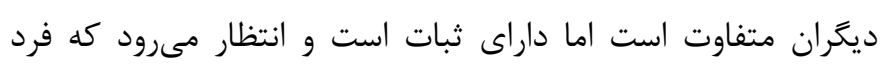

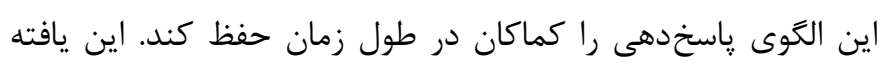

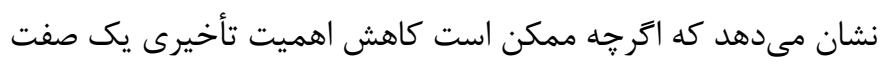

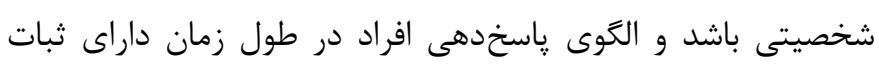

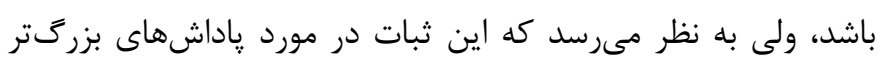

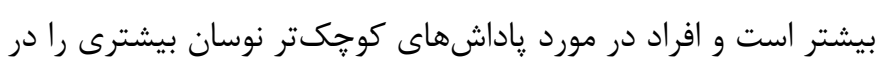
طول زمان از خود نشان مىدهند.

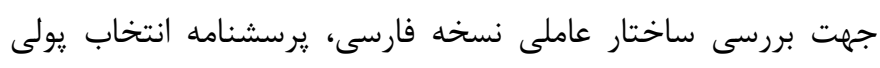

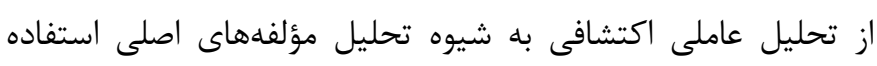

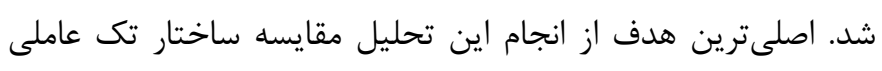

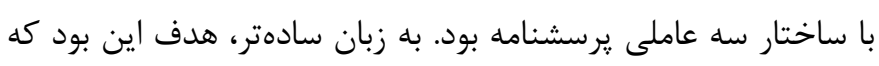

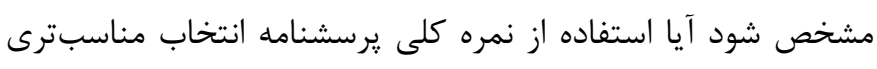

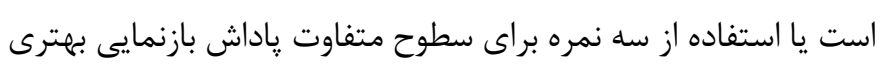

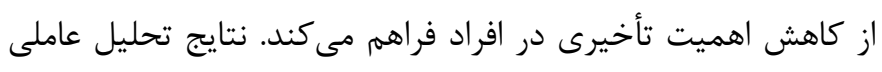

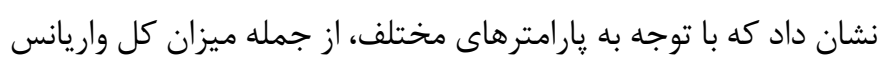
تبيين شده توسط راه حل انتخاب شده و بار عاملى مادهها روى عامل يا باديا

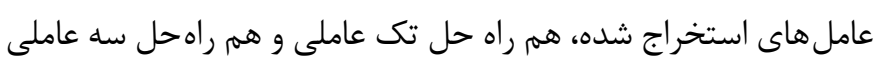

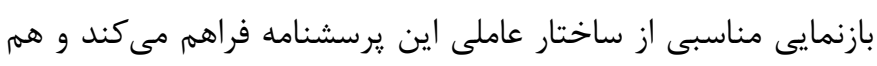

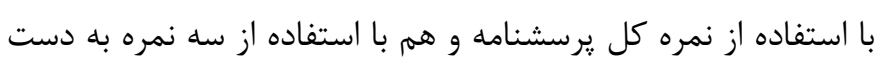

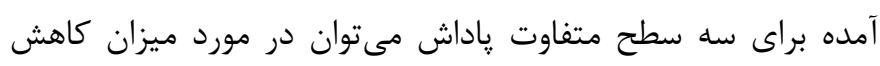


اندكى وجود دارد كه جه بسا ابزارهاى موجود هم به صورت تكاليف رايانهاى است كه اجراى آنها نه تنها زمان و هزينه بر بوده، بلكه اجراى آنها در بسيارى از موقعيتهاى بالينى و يزوهشى عملا امكان يذير نيست. لذا، ابزار حاضر با توجه به روايى و يايايى مناسب و نيز سهولت اجرا مى تواند ابزار مناسبى براى كسانى باشد كه قصد دارند با زمان و

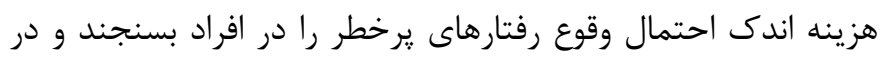
صورت نياز مداخلات پيشخيرانه لازم را براى اين افراد فراهم كنند.

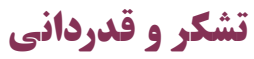
با سياس از تمام كسانى كه در انجام اين يزوهش ما را يارى كردند.

\section{References}

1. Odum AL. Delay discounting: I'm a k, you're a k. Journal of the Experimental Analysis of Behavior. 2011;96(3):427-439. 2. Madden GJ, Bickel WK. Impulsivity: The behavioral and neurological science of discounting. Washington, DC:American Psychological Association;2010.

3. Gray JC, Amlung MT, Palmer AA, MacKillop J. Syntax for calculation of discounting indices from the monetary choice questionnaire and probability discounting questionnaire. Journal of the Experimental Analysis of Behavior. 2016;106(2):156-163. 4. Rachlin H. Notes on discounting. Journal of the Experimental Analysis of Behavior. 2006;85(3):425-435.

5. Cyders MA, Littlefield AK, Coffey S, Karyadi KA. Examination of a short English version of the UPPS-P Impulsive Behavior Scale. Addictive Behaviors. 2014;39(9):1372-1376.

6. Green L, Myerson J. A discounting framework for choice with delayed and probabilistic rewards. Psychological Bulletin. 2004;130(5):769-792.

7. Kaplan BA, Amlung M, Reed DD, Jarmolowicz DP, McKerchar TL, Lemley SM. Automating scoring of delay discounting for the 21-and 27-item monetary choice questionnaires. The Behavior Analyst. 2016;39(2):293-304.

8. Bickel WK, Jarmolowicz DP, Mueller ET, Koffarnus MN, Gatchalian KM. Excessive discounting of delayed reinforcers as

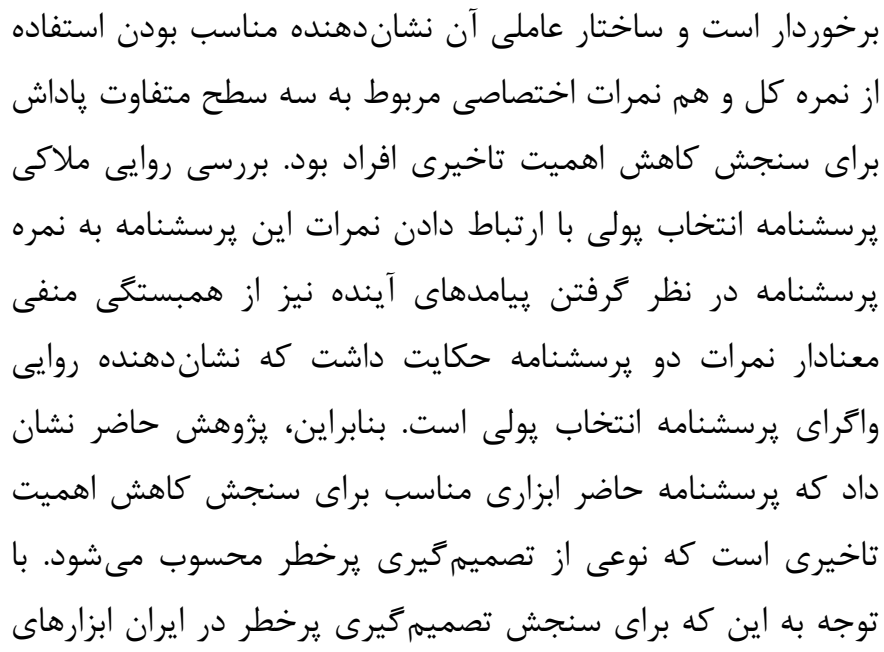

a trans-disease process contributing to addiction and other disease-related vulnerabilities: Emerging evidence. Pharmacology \& Therapeutics. 2012;134(3):287-297.

9. Amlung M, MacKillop J. Clarifying the relationship between impulsive delay discounting and nicotine dependence. Psychology of Addictive Behaviors. 2014;28(3):761-768.

10. Bickel WK, Koffarnus MN, Moody L, Wilson AG. The behavioral- and neuro-economic process of temporal discounting: A candidate behavioral marker of addiction. Neuropharmacology. 2014;76(Part B):518-527.

11. Amlung M, Petker T, Jackson J, Balodis I, MacKillop J. Steep discounting of delayed monetary and food rewards in obesity: A meta-analysis. Psychological Medicine. 2016;46(11):2423-2434.

12. Stojek MMK, MacKillop J. Relative reinforcing value of food and delayed reward discounting in obesity and disordered eating: A systematic review. Clinical Psychology Review. 2017;55:1-11.

13. Jarmolowicz DP, Landes RD, Christensen DR, Jones BA, Jackson L, Yi R, et al. Discounting of money and sex: Effects of commodity and temporal position in stimulant-dependent men and women. Addictive Behaviors. 2014;39(11):1652-1657. 14. Johnson MW, Johnson PS, Herrmann ES, Sweeney MM. 
Delay and probability discounting of sexual and monetary outcomes in individuals with cocaine use disorders and matched controls. PLoS One. 2015;10(5):e0128641.

15. Wiehler A, Peters J. Reward-based decision making in pathological gambling: The roles of risk and delay. Neuroscience Research. 2015;90:3-14.

16. Ferraro FR, Weatherly JN. Texting dependence, iPod dependence, and delay discounting. The American Journal of Psychology. 2016;129(2):161-168.

17. Johnson MW, Bickel WK. Within-subject comparison of real and hypothetical money rewards in delay discounting. Journal of the Experimental Analysis of Behavior. 2002;77(2):129-146. 18. Kirby KN, Marakovic NN. Delay-discounting probabilistic rewards: Rates decrease as amounts increase. Psychonomic Bulletin \& Review. 1996;3(1):100-104.

19. Kirby KN, Petry NM, Bickel WK. Heroin addicts have higher discount rates for delayed rewards than non-drug-using controls. Journal of Experimental Psychology General. 1999;128(1):7887.

20. Kirby KN. One-year temporal stability of delay-discount rates. Psychonomic Bulletin \& Review. 2009;16(3):457-462.
21. Kirby KN, Finch JC. The hierarchical structure of self-reported impulsivity. Personality and Individual Differences. 2010;48(6):704-713.

22. MacKillop J, Amlung MT, Few LR, Ray LA, Sweet LH, Munafo MR. Delayed reward discounting and addictive behavior: A meta-analysis. Psychopharmacology. 2011;216(3):305-321.

23. Epstein LH, Richards JB, Saad FG, Paluch RA, Roemmich JN, Lerman C. Comparison between two measures of delay discounting in smokers. Experimental and Clinical Psychopharmacology. 2003;11(2):131-138.

24. De Luca F, Benuzzi F, Bertossi E, Braghittoni D, Di Pellegrino G, Ciaramelli E. Episodic future thinking and future-based decision-making in a case of retrograde amnesia. Neuropsychologia. 2018;110:92-103.

25. Strathman A, Gleicher F, Boninger DS, Edwards CS. The consideration of future consequences: Weighing immediate and distant outcomes of behavior. Journal of Personality and Social Psychology. 1994;66(4):742-752.

26. Koff E, Lucas M. Mood moderates the relationship between impulsiveness and delay discounting. Personality and Individual Differences. 2011;50(7):1018-1022. 